\title{
TELEHEALTH: A TOOL FOR TECHNOLOGICAL INNOVATION WITH PERSPECTIVES OF PROMOTION OF INDIGENOUS HEALTHCARE IN THE STATE OF AMAZONAS, BRAZIL
}

Rejane Viana https://orcid.org/0000-0002-4948-7679

Alex Martins https://orcid.org/0000-0001-9657-2852

Vivian Marangoni https://orcid.org/0000-0001-8425-6449

Alessandro Bezerra https://orcid.org/0000-0002-6410-7099

Universidade do Estado do Amazonas, Manaus, AM, Brazil

\begin{abstract}
This article aims to present the Telehealth system implemented at indigenous villages in the state of Amazonas, Brazil. Faced with the peculiar configurations of the state of Amazonas, Telehealth and all its tools can alleviate the deficiency in the number of active health professionals working in this region, giving access to health, especially in indigenous villages. Although the Federal Constitution of 1988 brought the concept of universalization of health, it is known that the legislation alone does not make this right into reality. In this context, the implementation of the Telehealth tool is presented as an innovative format, with possibilities to reach out to a larger number of locations with difficult access, making it possible to reduce the factors that impede medical assistance. The indigenous population in the state of Amazonas is large in comparison to the other states of the federation, and amongst the thirtyfour (34) indigenous districts, seven (7) are entirely within the state's borders and are areas of great territorial extension. This research may contribute to the discussions about the need to seek innovative formats for healthcare of the indigenous population in remote regions.
\end{abstract}

Keywords: Amazonas, Telehealth, indigenous populations, healthcare, indigenous villages.

Manuscript first received: 2019-01-10. Manuscript accepted: 2019-02-01

Address for correspondence:

Rejane Viana, Universidade do Estado do Amazonas, Manaus, AM, Brazil. Email: rejaneviana@yahoo.com.br Alex Martins, Universidade do Estado do Amazonas, Manaus, AM, Brazil. Email: alexmartins1@usp.br

Vivian Marangoni, Universidade do Estado do Amazonas, Manaus, AM, Brazil. Email: vivislima@hotmail.com

Alessandro Bezerra, Universidade do Estado do Amazonas, Manaus, AM, Brazil. Email: alessandro.bezerra@usp.br 


\section{INTRODUCTION}

The peculiar configurations of Amazonas distinguish it from other Brazilian states, according to the IBGE - Brazilian Institute of Geography and Statistics (2012). With the reduced number of health professionals in its 62 municipalities, where often traveling is only possible by fluvial route. In this environment, Telehealth represents a tool of innovation to help where there is an impossibility of live participation by the health professionals, being its implementation able to promote healthcare, as it already shows in five indigenous villages in the state of Amazonas.

From the market's point of view of, Telehealth presents itself as a viable economic alternative for its various forms of use, and by opening of a growing demand for products targeted at healthcare, governments can expand their areas of operation. Professionally the market points to the need for professionals capable of handling differentiated tools (TAVEIRA, 2012).

Academically there is great and active field for professionals in telecommunications, in search for new information, technologies and incentives for research projects. Since the instrument we speak of allows for numerous forms of use, ranging from the orientation of professionals with pedagogical mediation to guidance provided through second opinions on the diagnosis (COSTA et al., 2017).

In the current world's context, with constant technological changes, high competitiveness, search for quality in products or services, more success depends on the company's ability to innovate technologically, placing new products in the market, at cost-benefit for the larger client, with better quality and at a greater speed than its competitors, which can be translated into benefits for society. In this manner, technologies are considered the most classic of the innovative activities, and has a prominent role, actively influencing the process of technological innovation and mastering "the state of the art" when it comes to innovation. (HICKS, 1999).

When (2011) understands the Productive Health Chain as a process where modern technologies are used from them to promote integrated and multi-professional actions, improving the quality of life of a population.

Along with this idea, the researches themed on "technological innovation" the development of innovative technologies can be a vehicle for advancement and social prosperity (BJORN, 2006; PLANING, 2017).

This research has an exploratory and descriptive approach, from secondary data collection, using* the document collection technique. Therefore*, this article does not intend* to investigate the technological innovations in the purist sense of the word. The present article used an approach that describes the use of a technological tool which offers possibilities of access to a basic right - health - being able to incorporate content and access to technology and improve medical assistance* for people residing in remote areas.

Undoubtedly, Amazonas is a large area to be covered, and a region with a shortage of healthcare professionals, according to COSTA et al. (2007). Data collected from the Regional Medical Council of Amazonas registered less than 4000 physicians in activity, with $80 \%$ residing in the state's capital. In view of this scenario, the authors investigated the reports and documents with records of the Brazilian indigenous telehealth's university program and, based on the analysis carried out, the following questions were developed: Can Telehealth assist health in remote areas? In what ways?

The article will be structured in five (5) sections, this first one being an initial contextualization followed by a description of the Brazilian Unified Health System and its integration of the indigenous healthcare subsystem, the indigenous reality in Amazonas, the Telehealth from 2011 and Telehealth with perspectives of use in indigenous' villages in the state of Amazonas. 


\section{THE BRAZILIAN UNIFIED HEALTH SYSTEM AND THE INTEGRATION OF THE INDIGENOUS HEALTHCARE SUBSYSTEM}

The idea of the Unified Health System (SUS) was based on the Federal Constitution of 1988, but was only regulated in 1990 by the Organic Laws of Health (LOS) n. 8,080 / 90 and n. 8142/90 (BRAZIL, 1988; 1990).

The purpose was to formulate and implement economic and social policies in the field of health, reducing the risks of diseases, ensuring conditions for universal and equal access to the health system. The approach would become one of prevention, besides allowing social control, which in turn would provide society's participation in management, through Local Health Councils (Brazil, 2012).

The creation of 34 DSEIs was official by the Ministry of Health through Administrative Rule no. 254 on January 31st, 2002 and only in 2010 by the Special Secretariat of Indigenous Health SESAI (BRASIL, 1999).

The map of the Ministry of Health - (MS) shows the delimitation of the Special Indigenous Sanitary Districts (DSEIs) throughout Brazil, with very extensive areas as it can be seen in the figure 1.

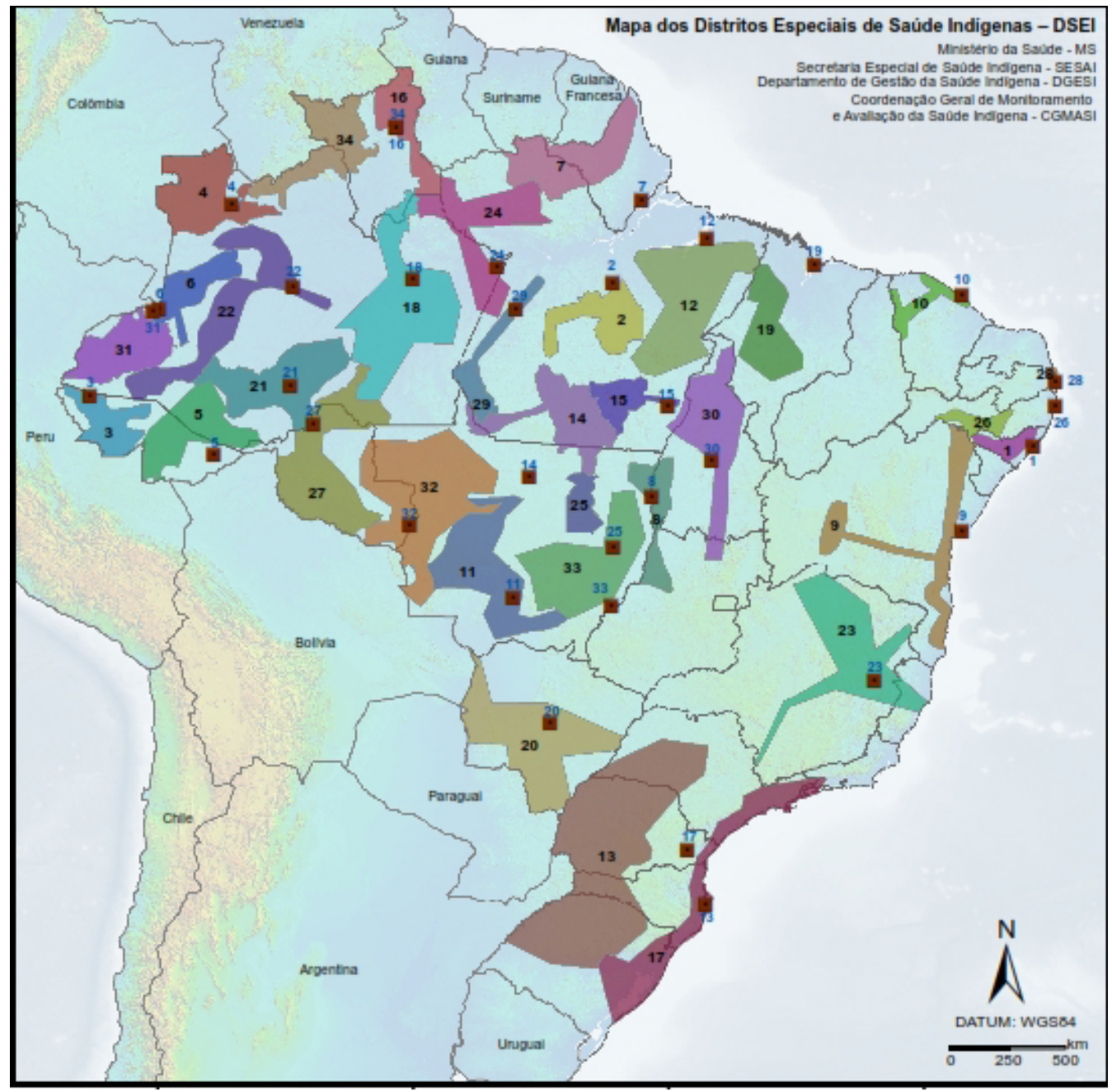

Figure 1 - Map of the Indigenous Special Health Districts- DSEIs

Source: Ministry of Health - MS (1999) 
The National Policy on HealthCare of Indigenous People was also integrated into the National Health Policy, with its foundations also contained in the Federal Constitution of 1988 and based on the Organic Laws of Health, recognizing the ethnic and cultural specificities of indigenous people and being regulated only in 1999 by Decree no.3.156 and Law 9.836 / 99 of September 23, 1999, which established the Subsystem of Attention to Indigenous Health within the scope of the SUS, passing the responsibility of indigenous health to the Union (BRASIL, 1999), thus the Special Indigenous Sanitary District (DSEI) becomes the central model of indigenous health management being directly linked to the Ministry of Health and managed by health councils having indigenous participation from the Districts in that healthcare policies must be proposed, which should seek to guarantee access to comprehensive healthcare, respecting the social and cultural development of these populations.

Table 1 lists the ten (10) Indigenous Special Sanitary Districts (DSEIs) that are at least partially within the area comprised by the state of Amazonas, but we can observe that only seven of them are entirely within Amazonas.

Table 1 - Special Indigenous Sanitary Districts (DSEIs) comprised wholly or partially in the state of Amazonas.

\begin{tabular}{cllc}
\hline & \multicolumn{1}{c}{ District } & Municipality Headquartes & State \\
\hline 4 & Alto Rio Negro & São Gabriel da Cachoeira & AM \\
5 & Alto Rio Purus & Rio Branco & AC \\
6 & Alto Rio Solimões & Tabatinga & AM \\
18 & Manaus & Manaus & AM \\
21 & Médio Rio Purus & Labrea & AM \\
22 & Médio Rio Solimões e afluentes & Tefé & AM \\
24 & Parintins & Parintins & AM \\
27 & Porto Velho & Porto Velho & RO \\
31 & Vale do Rio Javari & Atalaia do Norte & AM \\
34 & Yanomami & Boa Vista & RR \\
\hline
\end{tabular}

Source: Ministry of Health, 2018.

The DSEIs 5, 27 and 34 have their headquarters in other states. In table 1, they can be visualized in the map indicating the DSEIs and their locations.

\section{THE INDIGENOUS REALITY IN AMAZONAS}

The state of Amazonas is made up of 62 municipalities and a population of 3,341,096 inhabitants in an area of $1,570,745,680 \mathrm{~km}^{2}$. Traveling between the municipalities is made largely by waterway with a greater difficulty when it comes to indigenous areas, since a large part of this population is not located in the municipalities' headquarters, as IBGE's data points out (2010).

The distribution of the population that declared themselves to be indigenous in the last IBGE SENSUS (1990, 2010) and their domicile situation, so in the last three senses the northern region has higher numbers of the indigenous population in the rural area, where access and medical services are more scarce. 
The IBGE (2012) shows the large indigenous population present in the northern region of Brazil, and still has to be considered a large variation of ethnic groups with their peculiarities, even with groups that remain isolated.

Looking more closely at the seven (7) municipalities (Table 2) with the largest proportions of indigenous population in the country, all are in the state of Amazonas, and in São Gabriel da Cachoeira there is the significant majority number in the rural area.

In the analysis of the Federation Units, the State of Amazonas has the largest self-declared indigenous population in the Country, with 168.7 thousand; the smallest, Rio Grande do Norte, 2.5 thousand. Except for the State of Amazonas, which has an indigenous self-declared population of over 100,000, in most of the Federation Units (15) this population ranges from 15,000 to 60,000 indigenous (IBGE,2010) (Table 2).

Table 2 - Municipalities with the largest proportions of indigenous population in the country, by situation of domicile Amazonas / 2010. Percentage of population.

\begin{tabular}{lccc}
\hline \multicolumn{1}{c}{ Amazonas (2010) } & Total & Urban & Rural \\
\hline São Gabriel da Cachoeira & 76,6 & 57,8 & 95,5 \\
Santa Isabel do Rio Negro & 59,2 & 31,6 & 76,0 \\
São Paulo de Olivença & 47,7 & 15,6 & 74,3 \\
Atalaia do Norte & 41,4 & 6,3 & 70,7 \\
Barcelos & 32,5 & 12,3 & 48,1 \\
Amaturá & 31,9 & 10,9 & 55.0 \\
Benjamin Contant & 29,4 & 5,6 & 65,6 \\
\hline
\end{tabular}

Source: IBGE, 2010.

\section{THE TELEHEALTH SYSTEM AS OF 2011}

It is necessary to direct attention to the different meanings given to the terms Telehealth, Telemedicine and e-health. Although often applied as synonyms, Maldonado et al (2016, p S3) differentiates well "the terms", Telehealth refers to any kind of use of information services in relation to health from the instruments of technological communication, since Telemedicine is a category within Telehealth, "thus Telemedicine services are direct services aimed at professionals such as a service or health service, being the term e-health " a convergence of the Internet with health, that is, "any type of health service made possible by the Internet, including e-commerce"

The theme is gaining more importance each day, recommended in the resolution formulated at the 58th World Health Assembly in that countries must implement the products through the Internet, as well as the safe use of information and communication technologies in support of health issues. In Brazil, the Telehealth system was implemented by Decree No. 5.622, dated December 19 19th, 2005 and brings to us, through information technology, the possibility of offering valuable and useful education to teams specialized in family health, in areas difficult to access as is the case of the state of Amazonas, minimizing geographical distances (MINISTRY OF HEALTH, 2015).

As of 2011, with the edition of Ordinance No. 2,546, of October 27th, 2011, there is a redefinition with expansion of the Telehealth Program, which is now called the National Telehealth Network 
Program. The Decree in article 2 clarifies that Telehealth Brazil Network will provide professionals and workers of HealthCare Networks in the SUS four (4) types of activity comprising the services covered : Teleconsulting, Telediagnostics, Second Formative Opinion Training and Tele-education.

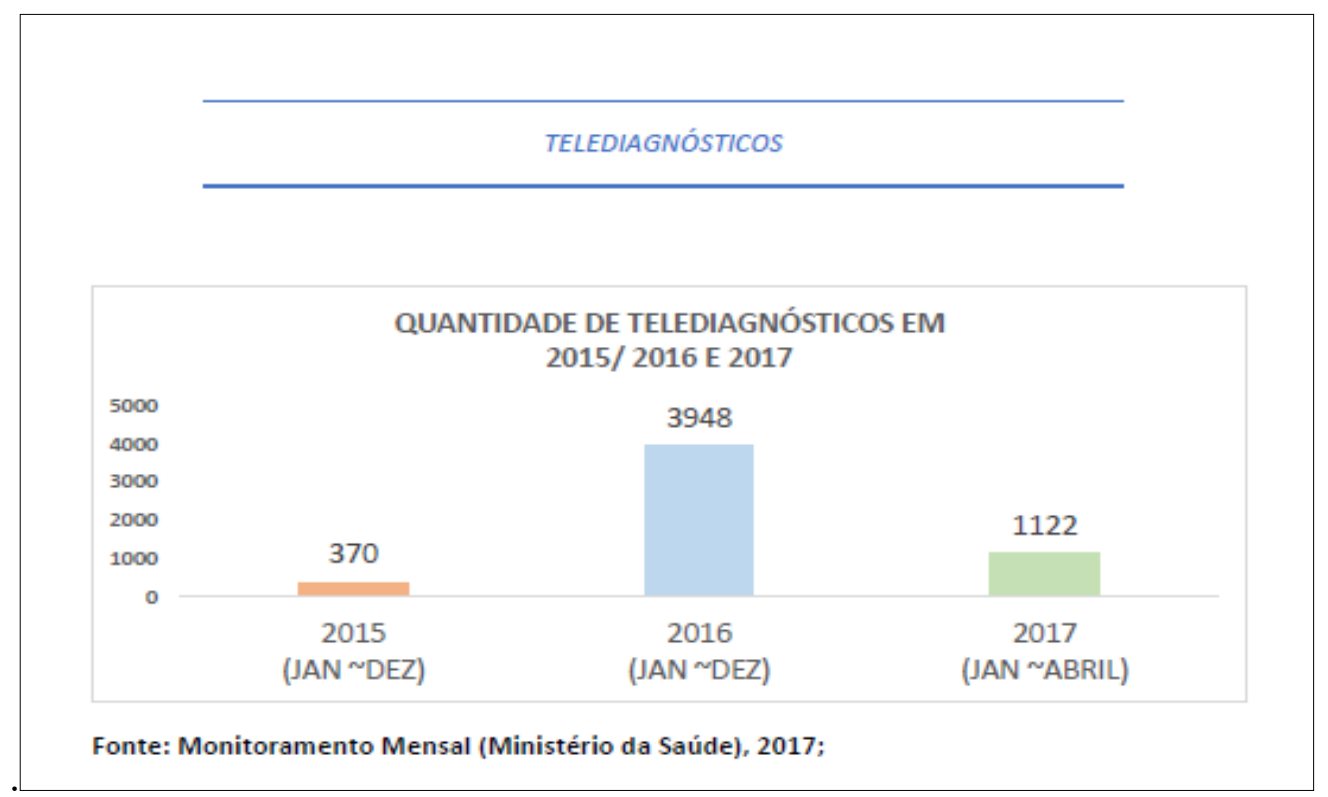

Figure 2 - Quantity of Telediagnostics performed in the triennium, 2015 - 2017.

Source: Internal reports, State University of Amazonas, 2017.

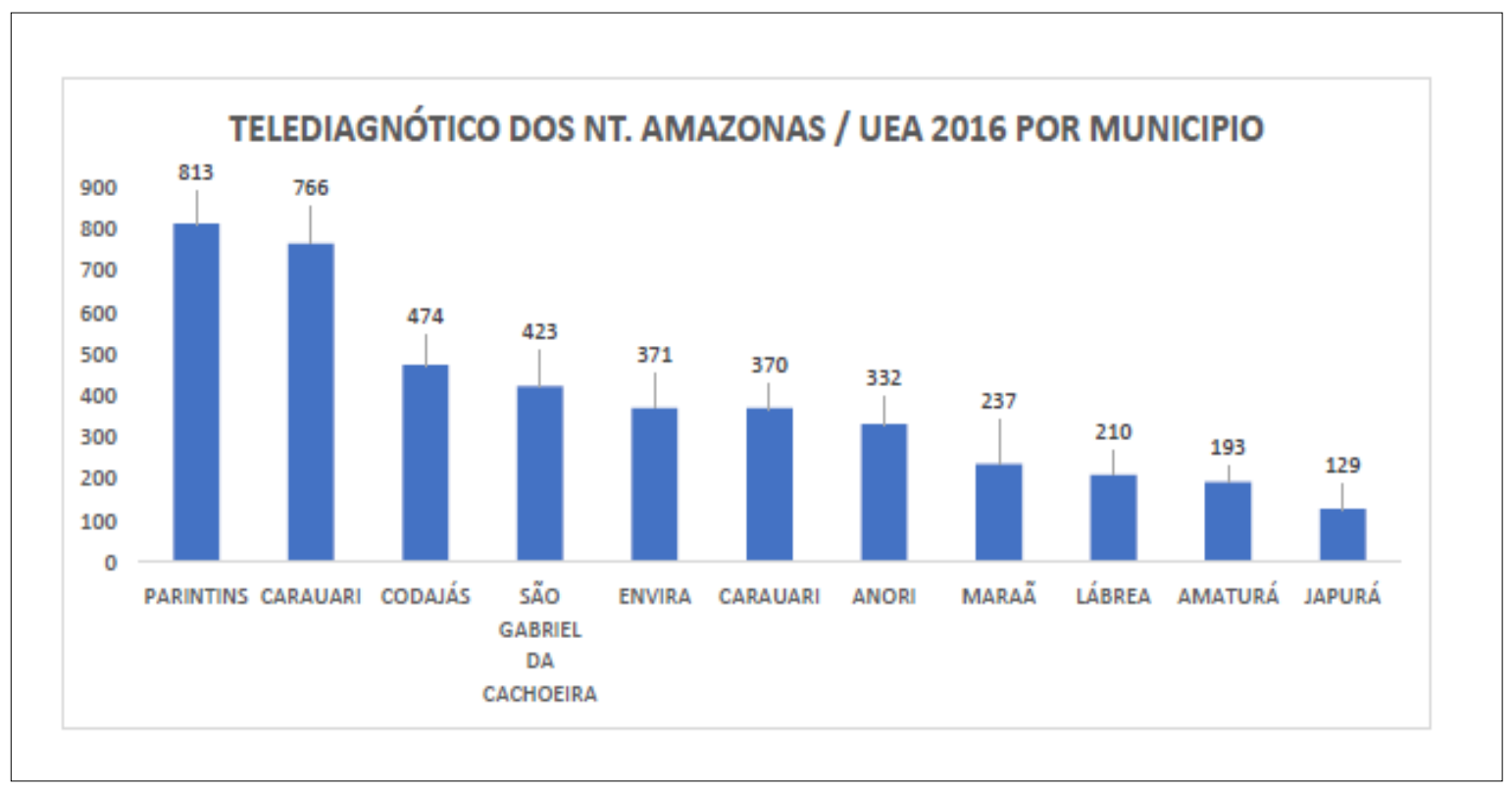

Figure 3 - Telediagnostics, year 2016, by municipality.

Source: Internal reports, State University of Amazonas, 2017. 


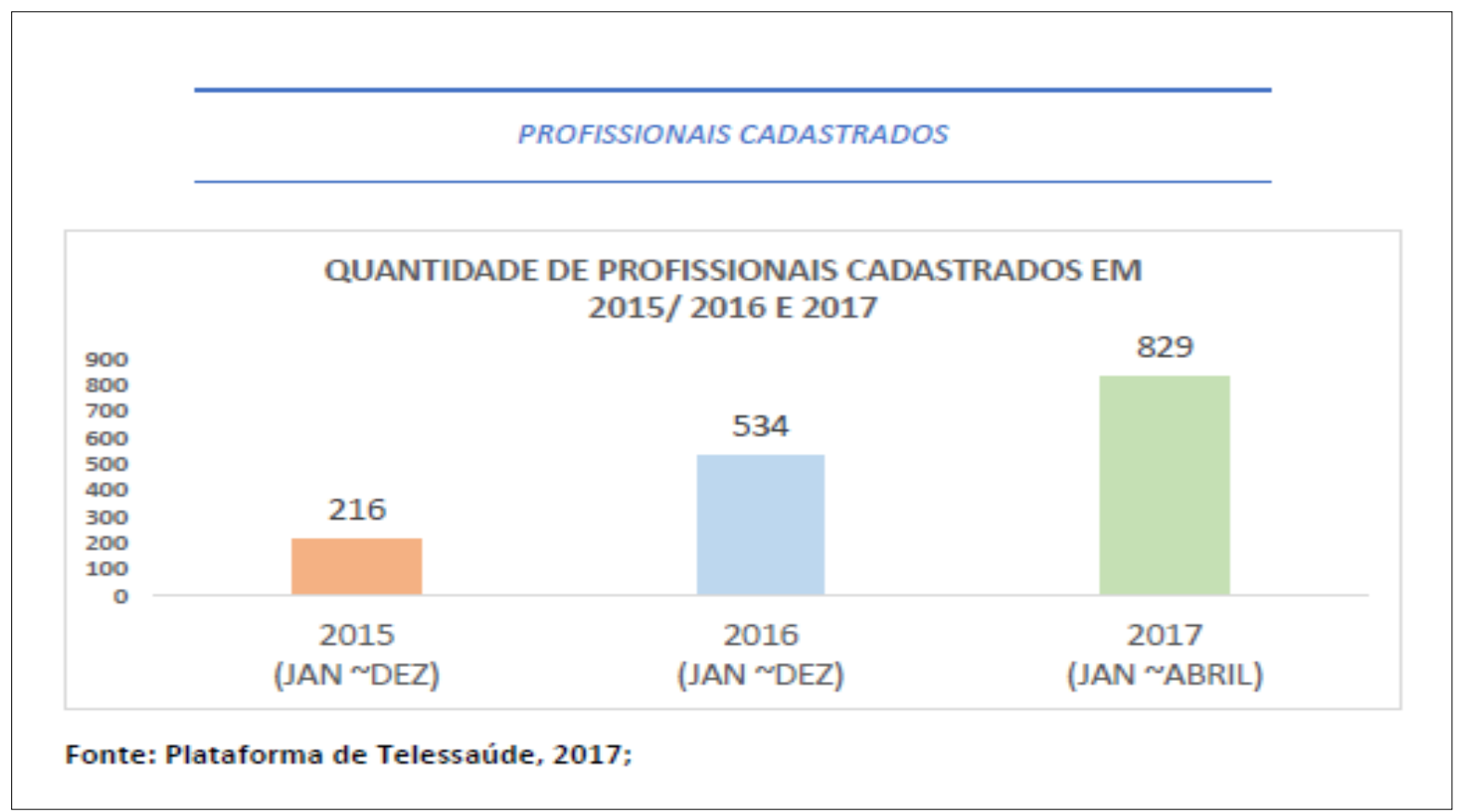

Figure 4 - Number of professionals registered in the triennium 2015-2017.

Source: Internal reports, State University of Amazonas, 2017.

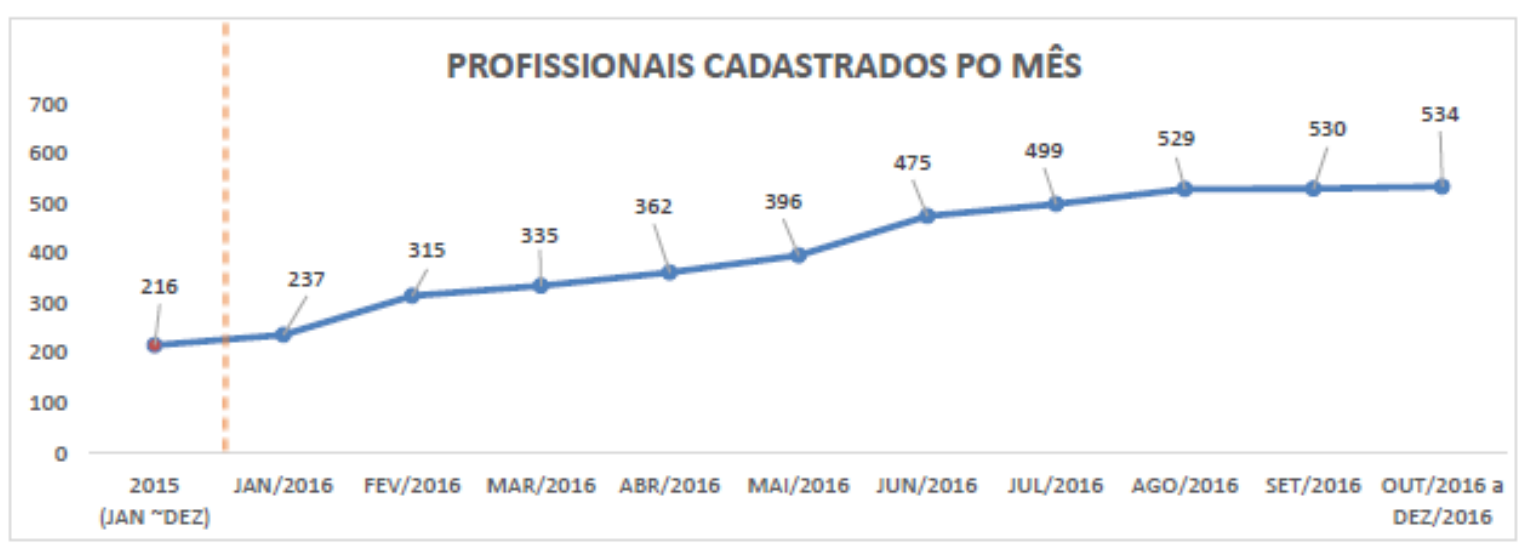

Figure 5 - Number of registered professionals demonstrates the adhesion of state professionals to the system.

Source: Internal reports, State University of Amazonas, 2017.

Telediagnostics is defined by the Decree as the service that uses information and communication technologies to perform diagnostic support services through distances (MALDONADO, 2011).

The second formative opinion would be the "systematized response, built based on a bibliographical review, on the best scientific and clinical evidences and on the organizing role of basic healthcare, to questions originated from Teleconsulting" (MALDONADO, 2011). 
The Second Formative Opinion is a tool that allows the development of educational activities with the use of real problem solving, giving a better training to the participants.

The fourth modality is Tele-education, which are the conferences, classes and courses taught through information and communication technologies.

Art. 4 Teleconsulting, Telediagnostic and Second Formative Opinions will be answered by the Technical-Scientific Centers based on the best and most upto-date clinical and scientific evidence available, adequate and pertinent to the context of origin of the request.

Single paragraph. The answer should emphasize the knowledge inherent in solving the problem and that will contribute to the permanent education of the professionals involved, with a view to increasing their capacity and autonomy in solving similar cases.

Art. 5 Theregulardeadlinefor sending the replyto Asynchronous Teleconsulting shall be established in protocols established by each Technical-Scientific Nucleus, in agreement with the State Management Committee, not exceeding a maximum period of 72 hours (seventy-two) of receiving the query.

Articles 4 and 5 show the parameters that determine the level of service required in each modality.

The web-based educational activities for teachers and experts bring knowledge and a rewarding exchange for everyone who uses the system. Teleconsulting is the consultation made through twoway telecommunication instruments, always among workers, professionals and managers of the health area and with the purpose of "clarifying doubts about clinical procedures, health actions and issues related to the work process" which can be synchronous when performed in real time, by chat, web or videoconference or asynchronous when it occurs through offline messages.

They are generated from the doubts of health professionals in face of diagnoses and in the need of a second opinion as a support tool (MALDONADO, 2011).

The following graphs point to increasing numbers in the area of tele-education, both in the volume of participants and in the number of activities.

The locations of the antenna installation points have a range that reaches the municipalities of the state of Amazonas, but still there are very large areas of emptiness. You can see the points in the report that there are health centers, hospitals, Basic Health Units or polyclinics, but there are specific facilities for Telehealth. 


\section{QUANTIDADE DE PARTICIPAÇÕES DE TELEDUCAÇÃO EM 2015/ 2016 E 2017}

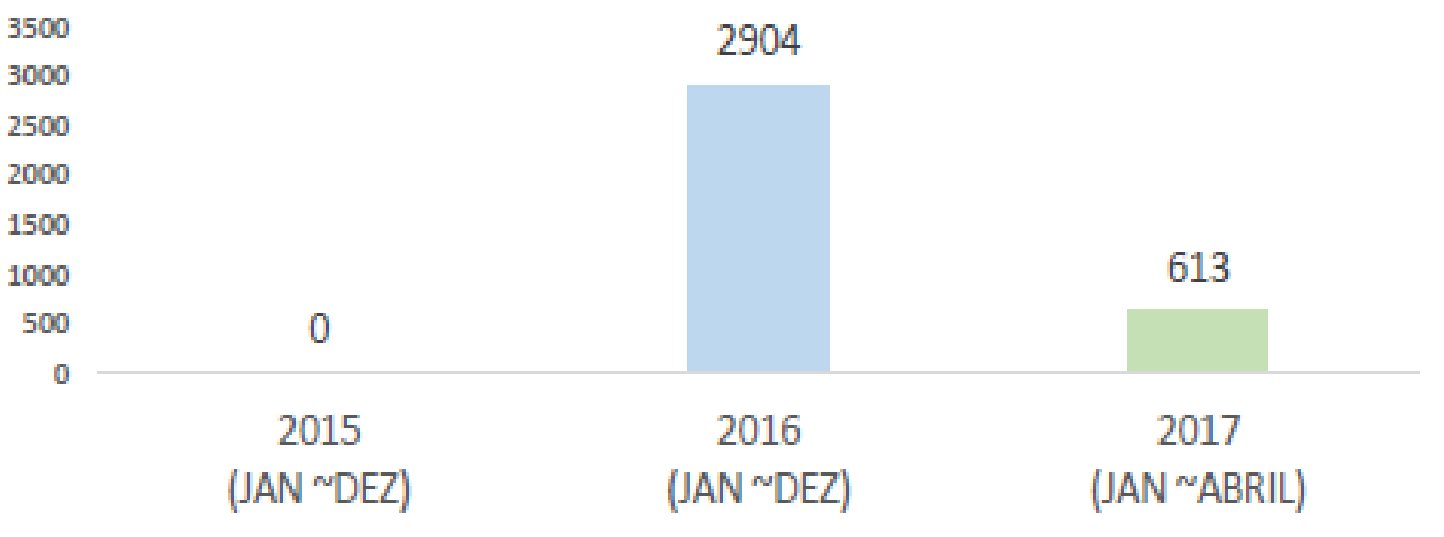

Figure 6 - Number of tele-education participations in the triennium 2015-2017.

Source: Internal reports, State University of Amazonas, 2017.

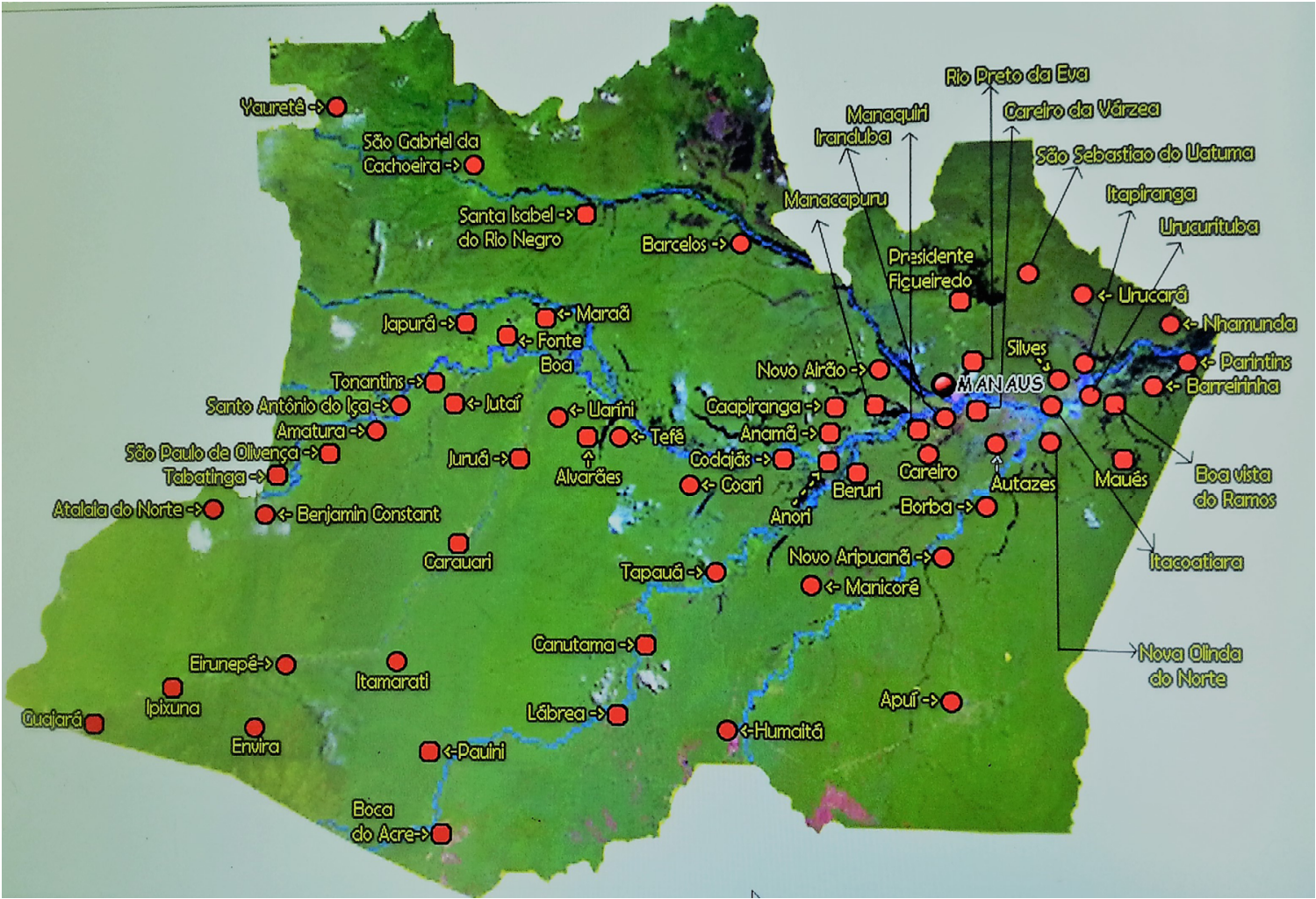

Figure 7 - Map of the installation points of the Telehealth antennas

Source: http://www.telessaudeam.org.br 


\section{TELESHEALTH AND ITS PROSPECTS IN INDIGENOUS VILLAGES IN THE STATE OF AMAZONAS}

In Brazil, indigenous populations are a minority, that is, it is estimated at 200,000 people. According to Langdon (1999), there is no exact data on the size of the population. There is not a single indigenous culture belonging to micro societies where about $40 \%$ of the 206 existing people, that is, 83 groups, have a population of up to 200 individuals, suffering "Malnutrition, tuberculosis, oral health problems, parasites, alcoholism, infant mortality, low life expectancy, etc. And there is still great concern about AIDS.

It is important to note that indigenous groups are in various stages of contact, and there are still isolated groups, so professionals dealing with indigenous health should be familiar with the nature of the indigenous health system.

In 2009 and 2010, Telehealth points (communication antennas) were implemented in indigenous areas in the State of Amazonas, located in indigenous areas. Taveira (2012) reports that one of them came to be implanted in the locality of Iauaretê, in the municipality of São Gabriel da Cachoeira, next to the Special Border Squadron - PEF and the Yauaretê base, which is located in the same district and belongs to DSEI Alto do Rio Negro, adding ten (10) indigenous communities, comprising about 15 ethnic groups, mostly of Tarian and Tukano origin. Considered to be of great proportions in the Indigenous Lands of the country, its population concentration is of 3,137 indigenous and the base at Umirituba, referenced to the municipality of Barreirinha and DSEI Parintins. It is situated on the banks of the river Andirá-Marau with about 1,343 indigenous. Currently both Points are inactive. The research also reports interviews of ten managers who were part of the Alto do Rio Negro and Parintins Indigenous Special Sanitary Districts. The research was impaired by the absence of reports or systematized documentation that could be analyzed.

Some aspects that hindered the use of Telehealth were identified as follows:

1. Disregarding cultural diversity: a differentiated understanding of the relationship with the indigenous must be considered. Selected indigenous populations were located in remote and culturally diverse areas, which hindered the implementation process;

2. Lack of adequate space for the installation of transmission equipment;

3. Difficult transportation of the equipment;

4. Supply with constant interruption of electrical energy;

5. The training of the workforce is pointed out as a fundamental instrument and it is difficult to maintain professionals in regions hard to access geographically. The job rotation's negative effects fall on the professional and patient bond.

Aspects related to the difficulties of use are important because they can help in future implantations of new points (antennas) or expansion of the Telehealth system to other areas.

\section{FINAL CONSIDERATIONS}

The data from the Telehealth reports analyzed in the study shows an adhesion of health professionals and the University of the State of Amazonas - UEA, with the university taking a preponderant role in this process. Despite the great distances between the municipalities of the state 
of Amazonas, the UEA is active and headquartered in 61 municipalities in the interior, plus the state capital (Manaus) where the headquarters is physically integrated, this facilitates the management of the points.

The model also saves time and financial resources, avoiding unnecessary traveling, and even though nothing can replace professional presence, it certainly minimizes the problems and isolation of professionals from the interior.

There is a need that should be highlighted, which is to develop skills necessary for the use of the Telehealth System. Thus, the University of the State of Amazonas - UEA established in the curricular matrix of their Medicine and Public Health Programs, classes of Telemedicine and Telehealth.

Finally, it can be considered that the communication system implemented by Telehealth, despite the difficulties encountered, is presented as an alternative capable of minimizing the effects of isolation in many areas, although there is still a need to improve the quality of the internet signal, source of complaints from the inhabitants of the interior of the state.

\section{REFERÊNCIAS}

BJORN T. Asheim and Meric S. Gertler. The Geography of Innovation: Regional Innovation Systems. The Oxford Handbook of Innovation. Jan, 2006. Disponível em: < http://www.oxfordhandbooks.com/ view/10.1093/oxfordhb/9780199286805.001.0001/oxfordhb-9780199286805-e-11 .

BRASIL. Constituição da República Federativa do Brasil de 1988. Disponível em:< http://www.planalto.gov. br/ccivil_03/constituicao/constituicaocompilado.htm.

BRASIL. Lei n 8.080, de 19 de setembro de 1990. Dispõe sobre as condições para a promoção, proteção e recuperação da saúde, a organização e o funcionamento dos serviços correspondentes e dá outras providências. Disponível em: $<$ http://www.planalto.gov.br/ccivil_03/leis/L8080.htm>.

BRASIL. Lei no 8.142, de 28 de dezembro de 1990. Dispõe sobre a participação da comunidade na gestão do Sistema Único de Saúde (SUS) e sobre as transferências intergovernamentais de recursos financeiros na área da saúde e dá outras providências. Disponível em: < http://www.planalto.gov.br/ccivil_03/leis/ L8142.htm>

BRASIL. Lei no 9.836, de 23 de setembro de 1999. Acrescenta dispositivos à Lei no 8.080, de 19 de setembro de 1990, que "dispõe sobre as condições para a promoção, proteção e recuperação da saúde, a organização e o funcionamento dos serviços correspondentes e dá outras providências", instituindo o Subsistema de Atenção à Saúde Indígena. Disponível em: http://www.planalto.gov.br/ccivil_03/leis/19836. htmhttp

BRASIL. Decreto no 3.156, de 27 de agosto de 1999. Dispõe sobre as condições para a prestação de assistência à saúde dos povos indígenas, no âmbito do Sistema Único de Saúde, pelo Ministério da Saúde, altera dispositivos dos Decretos $n^{\circ} \mathrm{s} 564$, de 8 de junho de 1992, e 1.141, de 19 de maio de 1994, e dá outras providências. Disponivel em: $<$ http://www.planalto.gov.br/ccivil_03/decreto/D3156.htm

BRASIL. Decreto $n^{0}$ 7.508, de 28 de julho de 2011, Regulamenta a Lei no 8.080, de 19 de setembro de 1990, para dispor sobre a organização do Sistema Único de Saúde - SUS, o planejamento da saúde, a assistência à saúde e a articulação interfederativa, e dá outras providências. Disponível em: $<$ http://www.planalto. gov.br/ccivil_03/_ato2011-2014/2011/decreto/d7508.htm> 
BRASILIA. Ministério da Saúde. Portaria no 2.546, de 27 de outubro de 2011. Redefine e amplia o Programa Telessaúde Brasil, que passa a ser denominado Programa Nacional Telessaúde Brasil Redes (Telessaúde Brasil Redes). Disponível em: < http://bvsms.saude.gov.br/bvs/saudelegis/gm/2011/prt2546_27_10_2011. html

CARTILHA SAÚDE INDÍGENA. Conselho Indigenista Missionário - CIMI. Edição eletrônica. Revisada. Outubro de 2013. Disponível em:<https://edisciplinas.usp.br/pluginfile.php/3258177/mod_resource/ content $/ 1 /$ brasil $\% 20$ cartilha $\% 20$ sa $\%$ c3\%bade $\% 20$ ind $\%$ c3\%adgena.pdf $>$

COSTA, C. de A.; SOUZA, P. E. de; ANDRADE, E. de O.; CAMPOS, P. V. M.; WEN, C. L.; BÖHM, G. M.. Pólo de Telemedicina da Amazônia.Universidade do Estado do Amazonas. PTA/UEA. Livro Telessaúde. 2007. Disponível em:<www.telessaudeam.org.br/downloads/documentos/PTA_livro_TELESSAUDE.pdf

HICKS D. Six reasons to do long-term research. Research Technology Management, Jul.-Aug. 1999, pg. 8-11. Disponível em: $<$ https://gvpesquisa.fgv.br/sites/gvpesquisa.fgv.br/ files/arquivos/andreassi__relacoes_entre_indicadores_de_pd_e_de_resultado_empresarial.pdf $>$ LANGDON, E. J.. Saúde e Povos Indígenas: Os desafios na virada do século. Venezuela: 1999. Disponivel em: <http://www.antropologia.com.br/tribo/nessi/textos/Margsav.htm>

MALDONADO, J. M. S. de V.; MARQUES, A. B.; CRUZ, A.. Telemedicina: desafios à sua difusão no Brasil. 2011. Disponível em: <http://www.scielo.br/pdf/csp/v32s2/pt_1678-4464-csp-32-s2-e00155615. pdf>.

MINISTÉRIO DA SAUDE. Manual Técnico Telessaude Preliminar. Versão eletrônica. Brasilia: 2015. Disponível em: $<$ http://189.28.128.100/dab/docs/portaldab/documentos/manual_tecnico_telessaude_ preliminar.pdf $>$

MINISTÉRIO DA SAÚDE E FUNASA MINISTÉRIO DA SAÚDE E FUNASA. Portaria MS n² 254, de 31 de janeiro de 2002. Aprova a Política Nacional de Atenção à Saúde dos Povos Indígenas. Disponível em:< http://www.indigena.mppr.mp.br/modules/conteudo/conteudo.php?conteudo=20>.

MINISTÉRIO DO PLANEJAMENTO, ORÇAMENTO E GESTÃO;INSTITUTO BRASILEIRO DE GEOGRAFIA E ESTATÍSTICA - IBGE. Diretoria de Pesquisas. Os indígenas no Censo Demográfico 2010. Rio de Janeiro. Disponível em: $<$ https://ww2.ibge.gov.br/indigenas/indigena_censo2010.pdf $>$

PLANING P. On the origin of innovations the opportunity vacuum as a conceptual model for the explanation of innovation. Journal of Innovation and Entrepreneurship. A Systems View Across Time and Space 2017; 6:5. Disponível em:<https://doi.org/10.1186/s13731-017-0063-2>.

PORTAL DA SAUDE. Ministério da Saúde. Disponível em<:http://portalsaude.saude.gov.br/index.php/oministerio/principal/secretarias/secretaria-sesai>.

OMS. Organização Mundial da Saúde. The Fifty-eighth World Health Assembly, RESOLUTIONS AND DECISIONS. WHA58.28 eHealth - World Health Organization Disponível em: $<$ http://www.who.int/ healthacademy/media/WHA58-28-en.pdf $>$.

TAVEIRA, Z. Z. Implantação da Telessaúde na Atenção à Saúde Indígena Dissertação apresentada como requisito parcial para obtenção do título de Mestre em Saúde Coletiva pelo Programa de Pós-Graduação em Saúde Coletiva da Universidade de Brasília.Brasilia: 2012. Disponível em: < http://www.scielo.br/ scielo.php?pid=S0102-311X2014000801793\&script $=$ sci_abstract\&tlng=pt $>$

TELESSAUDE AMAZONAS. Universidade do Estado do Amazonas. Telessaúde Brasil - Núcleo Amazonas. Manaus-AM. Disponível em: $<$ http://www.telessaudeam.org.br/newsite/index.html

WEN, C. L. Telemedicina e Telessaúde: Inovação e Sustentabilidade. As experiências da Disciplina de Telemedicina (DTM) da Faculdade de Medicina da Universidade de São Paulo. São Paulo: 2011. Disponível em:www.telessaude.uerj.br/resource/goldbook/pdf/5.pdf. 